\title{
Milk protein responses in dairy cows to changes in postruminal supplies of arginine, isoleucine, and valine
}

\author{
M. N. Haque,${ }^{*} \dagger$ H. Rulquin, ${ }^{*} \dagger$ and S. Lemosquet ${ }^{*} \dagger^{1}$ \\ *INRA, UMR1348 Pegase, F-35590 Saint-Gilles, France \\ †Agrocampus Ouest, UMR1348 Pegase, F-35000 Rennes, France
}

\begin{abstract}
An ideal profile of essential AA (EAA) can improve the efficiency of metabolizable protein (or PDIE, the equivalent in the INRA feeding system) utilization in dairy cows. Compared with other EAA, existing recommendations for the requirements of Arg, Ile, and Val are few and inconsistent. Four multiparous Holstein dairy cows at $22 \pm 6 \mathrm{wk}$ of lactation received 4 treatments (duodenal infusions of $445 \pm 22.4 \mathrm{~g} / \mathrm{d}$ of an EAA mixture complementing a low-protein diet in a $4 \times 4$ Latin square design with a period length of $1 \mathrm{wk}$ ). The control treatment provided a balanced supply (in $\%$ of PDIE) of $5.1 \%$ Arg, $5.2 \%$ Ile, and $5.9 \%$ Val, whereas in the 3 subsequent treatments of -Arg, -Ile, and -Val, the concentrations of these $3 \mathrm{EAA}$ were reduced to 3.5, 4.1 , and $4.5 \%$, respectively. All treatments were made isonitrogenous and were balanced to provide 7 other EAA (Lys, Met, His, Leu, Phe, Thr, and Trp), according to the recommendations described in the literature. Combined, the diet and the infusions provided $14.3 \pm$ $0.1 \%$ crude protein on a dry matter basis, and $66.0 \pm$ $1.2 \mathrm{~g}$ of PDIE/Mcal of net energy for lactation. Neither dry matter intake $(19.2 \mathrm{~kg} / \mathrm{d})$ nor milk yield $(30.4 \pm$ $0.4 \mathrm{~kg} / \mathrm{d}$ ) was affected by treatments. The -Arg and - Ile treatments did not modify milk protein synthesis or the efficiency of $\mathrm{N}$ utilization. However, the -Val treatment decreased milk protein content by $4.9 \%$ and milk crude protein content by $4.3 \%$, and tended to decrease the efficiency of $\mathrm{N}$ use for milk protein yield by $3.7 \%$ (compared with the control). These effects of Val were related to a decrease in the plasma concentration of Val as well as a trend toward decreasing plasma concentrations of Met, His, and the sum of all EAA and nonessential AA in the - Val treatment, which indicates a different utilization of all AA in response to the Val deficit. The deletion of Ile, compared with the deletion of Val, tended to decrease the milk protein-to-fat ratio by $3.8 \%$. In conclusion, the supply of Arg at $3.5 \%$ of
\end{abstract}

Received April 11, 2012

Accepted October 2, 2012.

${ }^{1}$ Corresponding author: Sophie.Lemosquet@rennes.inra.fr
PDIE was not limiting for milk protein synthesis. The slight effect on the milk protein-to-fat ratio caused by decreasing the supply of Ile suggests a need to reevaluate the Ile requirement more precisely. A low Val supply could be limiting for milk protein synthesis, provided that the requirements of Lys, Met, and His are met. Key words: branched-chain amino acid, arginine, milk protein, dairy cow

\section{INTRODUCTION}

Balancing the essential AA (EAA) profile of dairy cow diets can improve the efficiency of conversion of MP [(NRC, 2001) or protein truly digestible in the small intestine (PDI; INRA, 1989)] into milk protein (Rulquin et al., 1993; Schwab, 1996; NRC, 2001). In dairy cows, aside from the studies on Lys and Met, very few postruminal infusion studies are available in which supplies of other EAA were altered to test their lactation responses. This is especially true for Arg, Ile, and Val. Arginine can indirectly affect the synthesis of milk protein by limiting the supply of Pro and Glu (Mepham, 1982). However, in no research has a response been observed on milk protein synthesis by changing the supply of Arg (Schwab et al., 1976; Vicini et al., 1988; Doepel and Lapierre, 2011). In contrast, Ile supply has been variously shown to increase both milk yield (Robinson et al., 1999) and milk protein content (Schwab et al., 1976), as well as have no effect (Korhonen et al., 2002). Increasing the supply of Val has been shown to either increase (Schwab et al., 1976) or have no effect (Schwab et al., 1976; Korhonen et al., 2002) on milk protein synthesis. Therefore, it has been difficult to establish recommendations for the optimal amounts of these AA in MP or PDI. The lowest recommended levels of intestinal supplies for Arg, Ile, and Val are proposed by Fraser et al. (1991) at 3.1, 4.4, and $5.3 \%$ of PDI supplied by RUP and by microbial protein from rumen-fermented OM (PDIE; INRA, 1989), respectively. The highest reported concentrations are $4.8,5.3$, and $6.1 \%$ of PDIE, respectively (Doepel et al., 2004). Although these EAA do not appear to be among the most limiting AA, it is important in developing an 
"ideal" EAA profile to know how changing their supplies may affect lactation responses.

For this experiment, we used the ideal recommendations for 9 EAA (Arg, Ile, Val, Lys, Met, His, Leu, Phe, and Thr) based on the literature (Fraser et al., 1991; Doepel et al., 2004; Rulquin et al., 2007), and tested the effect of removing Arg, Ile, and Val on lactation in an isonitrogenous condition. The decision to decrease the supply of these EAA was based on the observation that the deletion of an AA has more pronounced effects than AA supplementation (Rulquin and Pisulewski, 2006; Weekes et al., 2006; Doepel and Lapierre, 2011). Furthermore, the higher supply levels of Arg, Ile, and Val used in this experiment were the highest supply levels recommended in the literature (Doepel et al., 2004), whereas upon removal, we intended to go well below the lowest recommended levels (Fraser et al., 1991). The treatments were made isonitrogenous to ensure adequate synthesis of the nonessential AA (NEAA) because Arg, Ile, and Val serve as sources of $\mathrm{C}$ and a-amino $\mathrm{N}$ for NEAA synthesis (Wohlt et al., 1977). We expected to see a negative effect on the lactation performance of dairy cows by supplying an imbalanced AA profile or a deficient level of the test AA (Arg, Ile, and $\mathrm{Val})$.

\section{MATERIALS AND METHODS}

\section{Cows}

The experiment was carried out at the INRA UMR1348 experimental farm of Méjusseaume $\left(1.71^{\circ} \mathrm{W}\right.$, $48.11^{\circ} \mathrm{N}$; Brittany, France) in June 2010. Four multiparous Holstein cows fitted with T-shaped duodenal cannula (10 to $15 \mathrm{~cm}$ distal to the pylorus) were used in this study. One week before the start of the experiment, the cows were at $149 \pm 54 \mathrm{DIM}$, their average BW was $634 \pm 58 \mathrm{~kg}$, and their average daily milk yield was 31 $\pm 2.2 \mathrm{~kg} / \mathrm{d}$, with protein and fat contents of $3.0 \pm 0.1 \%$ and $3.9 \pm 0.5 \%$, respectively. Before the beginning of the experiment, they were provisionally fitted with catheters $(30 \mathrm{~cm}$; $1.02 \mathrm{~mm}$ i.d.; $2.16 \mathrm{~mm}$ o.d.; Fisher Scientific, Strasbourg, France) in the left jugular vein for $7 \mathrm{~d}$. The experiment was conducted in accordance with the National Legislation on Animal Care (certified by the French Ministry of Agriculture, Agreement No. C35-275-23). The cows were housed in individual tie stalls and had free access to feed and water.

\section{Experimental Design, Treatments, and Feedings}

All treatments were isonitrogenous and were composed of a basal diet and 4 different infusions of AA [control (CTRL), -Arg, -Ile, - Val] mixtures in the
Table 1. Composition of the AA mixture infused daily

\begin{tabular}{lrrrr}
\hline & \multicolumn{4}{c}{ Treatment $^{1}$} \\
\cline { 2 - 5 } AA, g/d & CTRL & -Arg & -Ile & -Val \\
\hline Arg & 30 & & 30 & 30 \\
Glu & 136 & 237 & 178 & 187 \\
His & 26 & 25 & 27 & 27 \\
Ile & 19 & 19 & & 21 \\
Leu & 26 & 25 & 29 & 29 \\
Lys & 40 & 39 & 43 & 43 \\
Met & 17 & 17 & 18 & 18 \\
Phe & 45 & 45 & 49 & 49 \\
Ser & 33 & 33 & 38 & 38 \\
Thr & 1 & & 1 & 1 \\
Trp & 8 & 8 & 8 & 8 \\
Val & 23 & 23 & 26 & \\
\hline
\end{tabular}

${ }^{1} \mathrm{CTRL}=\mathrm{Arg}$, Ile, and Val included in the AA mixture; $-\mathrm{Arg}=\mathrm{Arg}$ removed from the AA mixture; -Ile = Ile removed from the AA mixture; - Val $=$ Val removed from the AA mixture.

duodenum according to a $4 \times 4$ Latin square design with a 7 -d period. The CTRL treatment contained an ideal concentration of Arg, Ile, Val, Lys, Met, Leu, His, Phe, Thr, and Trp in the intestinal protein for dairy cows based on the results found in the literature (Doepel et al., 2004; Rulquin et al., 2007). For the other treatments (i.e., - Arg, - Ile, and - Val), the cows received infusions containing similar concentrations of all EAA as CTRL, except that Arg, Ile, and Val were removed from the mixture, respectively. On average, the diet supplied $77 \%$ of the total PDIE, whereas $23 \%$ of PDIE was provided in the form of free AA ( $445 \pm 35$ $\mathrm{g} / \mathrm{d}$ ) infused in the duodenum (Table 1). The basal diet and AA infusions were formulated to ensure a proteinto-energy ratio of $66.0 \pm 1.2 \mathrm{~g}$ of PDIE/Mcal of $\mathrm{NE}_{\mathrm{L}}$, as proposed by Vérité and Delaby (2000).

The basal diet was formulated to provide (per $\mathrm{kg}$ of DM) 1.52 Mcal of $\mathrm{NE}_{\mathrm{L}}$ and $12.4 \% \mathrm{CP}$, corresponding to $77 \mathrm{~g}$ of PDIE (Table 2). Furthermore, the diet was formulated in such a way that the 2 assigned PDI values [i.e., PDIE and PDI supplied by RUP and by microbial protein from rumen-degraded dietary N (PDIN), respectively; INRA 1989] remained equal. The diet was offered in a restricted amount per period per cow. Additionally, a lactation persistency of $98 \%$ for milk yield was applied to predict the quantity of the diet to be offered. The diet was composed (on DM basis) of $63.4 \%$ corn silage, $19.8 \%$ energy concentrate $1,14.9 \%$ energy concentrate $2,0.4 \%$ urea, and $1.5 \%$ mineral and vitamin premix (Table 2). The predicted intestinal flows of AA are presented in Table 3.

The CTRL treatment was formulated to ensure that it contained (in \% of PDIE) $7.3 \%$ of Lys, $2.5 \%$ of Met, $8.9 \%$ of Leu, $3.0 \%$ of His, and $4.0 \%$ of Thr, as proposed by Rulquin et al. (2007), whereas the supplies of Arg (4.8\% of PDIE), Ile (5.3\% of PDIE), and Val (6.1\% of 
HAQUE ET AL.

Table 2. Chemical composition and nutritive value of the feedstuffs and $\operatorname{diet}^{1}$

\begin{tabular}{lccccc}
\hline Item & Corn silage & Concentrate $1^{2}$ & Concentrate $2^{3}$ & Urea & Diet \\
\hline DM $\%$ & 38 & 90 & 90 & 98 & 56 \\
\cline { 2 - 5 } & & & per kg of DM & & \\
OM, g & 960 & 973 & 860 & 929 \\
CP, g & 62 & 269 & 131 & 2,875 & 124 \\
Ether extract, g & 30 & 49 & 32 & 33 \\
NDF, g & 389 & 98 & 179 & 293 \\
ADF, g & 220 & 28 & 73 & 156 \\
ADL, g & 22 & 4.0 & 21 & 18 \\
Crude cellulose, g & 207 & 21 & 56 & 383 \\
Starch, g & 323 & 24 & 357 & 21 \\
PDIA, g & 14 & 162 & 52 & 76 \\
PDIN, g & 38 & 95 & 93 & 77 \\
PDIE, g & 67 & 1.89 & 110 & 1.52 \\
NE, Mcal & 1.60 & & 1.89 & \\
\hline
\end{tabular}

${ }^{1}$ The diet contained corn silage $(63.4 \%)$, concentrate $1(19.8 \%)$, concentrate $2(14.9 \%)$, urea $(0.4 \%)$, and mineral mixture (1.5\%). The mineral and vitamin premix (Cooperl Arc Atlantique, Lamballe, France) was composed (on DM basis) of calcium carbonate (52\%), dicalcium phosphate $(23 \%)$, wheat middlings $(11 \%)$, sugarcane molasses (8\%), magnesium oxide and other additives (6\%) including 600,000 IU of vitamin A and $80,000 \mathrm{IU}$ of vitamin $\mathrm{D}_{3}$.

${ }^{2}$ The cereal concentrate 1 (Cooperl Arc Atlantique) was composed (on a DM basis) of corn grains (85.3\%), corn gluten meal $(5.4 \%)$, sugarcane molasses $(2.6 \%)$, salt $(1.2 \%)$, and urea $(5.5 \%)$.

${ }^{3}$ The cereal concentrate 2 (Cooperl Arc Atlantique) was composed (on a DM basis) of wheat (20\%), corn $(20 \%)$, barley $(20 \%)$, pressed sugar beet $(20 \%)$, fine wheat bran (15\%), sugarcane molasses (3\%), vegetable oil $(1 \%)$, and salt $(1 \%)$.

${ }^{4} \mathrm{PDIA}=$ fraction of protein digested in the small intestine supplied only by RUP (INRA, 1989).

${ }^{5} \mathrm{PDIN}=$ protein digested in the small intestine supplied by RUP and by microbial protein from rumendegraded dietary N (INRA, 1989).

${ }^{6} \mathrm{PDIE}=$ protein digested in the small intestine supplied by RUP and by microbial protein from rumenfermented OM (INRA, 1989).

PDIE) were selected based on the recommendations of Doepel et al. (2004). Because the concentration of Trp in the INRA (2007) system was not known, the quantity of Trp for duodenal infusion was calculated by applying the Trp-to-Lys ratio (0.18) in milk protein (Swaisgood, $1995)$ to the value of $7.3 \%$ of Lys. Because of its insolubility in water, the supply of Tyr was ensured by supplying extra Phe (a precursor of Tyr), so that the Phe + Tyr concentration remained at $9.2 \%$ of PDIE, as is present in milk protein (Swaisgood, 1995). In the treatments - Arg, -Ile, and - Val, the concentrations of Arg, Ile, and Val were reduced to 3.5, 4.1, and 4.5\% of PDIE, respectively, when removed from the infusion mixtures containing other EAA in similar proportions to the CTRL treatment. The NEAA, namely, Glu (20.4 $\pm 1.9 \%$ of PDIE) and Ser $(5.5 \pm 0.1 \%$ of PDIE), were used to make the 4 AA infusions isonitrogenous. Further, it was taken into account that their concentration in PDIE (diet and infusions) was not greater than their concentration in milk (Swaisgood, 1995). The percentage of EAA in PDIE varied from 45 to $48 \%$ in the different treatments and was close to the recommendations of Doepel et al. (2004).

The free AA (L-Lys HCl, L-His $\mathrm{HCl} \mathrm{H}_{2} \mathrm{O}$, L-Leu, LPhe, L-Thr, L-Trp, L-Arg, L-Ile, L-Val, L-GluNa $\mathrm{H}_{2} \mathrm{O}$, and L-Ser) were obtained from Ajinomoto Co. Inc. (Tokyo, Japan); DL-Met was obtained from Adisseo (Rhodimet, Commentry, France). The AA were dissolved in $10 \mathrm{~L}$ of tap water and infused continuously $(24 \mathrm{~h})$ on a daily basis in the duodenum by using a peristaltic pump (Gilson, Villers de bel, France). Diets were offered at 0830 and $1800 \mathrm{~h}$; cows were milked twice a day at 0715 and $1715 \mathrm{~h}$.

\section{Measurement, Sample Collection, and Preparation}

The quantity of the diet offered and orts were weighed daily. Samples of corn silage and concentrate were collected to determine DM on a daily or weekly basis, respectively, in a forced-air oven at $80^{\circ} \mathrm{C}$ for $48 \mathrm{~h}$. After determining DM content of the corn silage, the quantity of corn silage offered was adjusted every day to ensure the same delivery of DM on each experimental day. The samples (corn silage and concentrate) were ground to pass a $0.5-\mathrm{mm}$ screen and were subjected to AA content analysis using HPLC (Alliance System; Waters, Guyancourt, France) following protein hydrolysis with $6 \mathrm{~N} \mathrm{HCl}$ at $110^{\circ} \mathrm{C}$ for $23 \mathrm{~h}$ under reflux. The AA contents were measured by cation exchange chromatography after acid hydrolysis for $24 \mathrm{~h}$ (Directive 98/64/ 
Table 3. Amino acid composition of feedstuffs by percentage of 18 AA and recalculated values in the $\mathrm{AADI}^{1}$ system

\begin{tabular}{|c|c|c|c|}
\hline Item & Corn silage & Concentrate 1 & Concentrate 2 \\
\hline & & $-\%$ of $18 \mathrm{AA}$ & \\
\hline Ala & 9.7 & 7.6 & 5.4 \\
\hline Arg & 2.2 & 4.2 & 5.9 \\
\hline Asp & 8.2 & 6.7 & 8.0 \\
\hline Cys & 1.8 & 2.4 & 2.4 \\
\hline Glu & 15.0 & 19.6 & 20.1 \\
\hline Gly & 5.1 & 3.5 & 5.0 \\
\hline His & 2.4 & 2.6 & 2.7 \\
\hline Ile & 4.4 & 3.6 & 3.8 \\
\hline Leu & 11.9 & 13.0 & 8.4 \\
\hline Lys & 3.5 & 2.7 & 4.4 \\
\hline Met & 1.8 & 1.9 & 1.8 \\
\hline Phe & 4.9 & 5.0 & 4.8 \\
\hline Pro & 8.8 & 8.7 & 8.2 \\
\hline Ser & 5.1 & 4.9 & 4.8 \\
\hline Thr & 4.4 & 3.8 & 4.1 \\
\hline Trp & 0.66 & 0.71 & 1.42 \\
\hline Tyr & 4.0 & 4.4 & 3.6 \\
\hline Val & 6.2 & 4.7 & 5.3 \\
\hline AlaDI & 7.0 & 6.9 & 6.5 \\
\hline ArgDI & 4.4 & 4.6 & 4.9 \\
\hline AspDI & 10.8 & 10.5 & 10.2 \\
\hline GluDI & 13.3 & 14.1 & 15.2 \\
\hline GlyDI & 6.1 & 5.8 & 6.0 \\
\hline HisDI & 2.0 & 2.0 & 2.2 \\
\hline IleDI & 5.4 & 5.3 & 5.1 \\
\hline LeuDI & 8.8 & 9.1 & 8.5 \\
\hline LysDI & 7.1 & 6.8 & 6.5 \\
\hline MetDI & 2.0 & 2.0 & 1.9 \\
\hline PheDI & 5.0 & 5.1 & 5.0 \\
\hline ProDI & 4.6 & 4.7 & 5.3 \\
\hline SerDI & 4.7 & 4.7 & 4.7 \\
\hline ThrDI & 5.2 & 5.1 & 5.0 \\
\hline TyrDI & 4.5 & 4.6 & 4.2 \\
\hline ValDI & 5.9 & 5.7 & 5.7 \\
\hline
\end{tabular}

${ }^{1} \mathrm{AADI}=\mathrm{AA}$ digestible in the small intestine $[1 \mathrm{~g}$ of AADI is equal to $1 \mathrm{~g}$ of PDIE; Rulquin et al. $(1998,2001)$ and INRA (2007)]. The AADI system does not account for Trp and Cys.

${ }^{2} \mathrm{PDIE}=$ protein digested in the small intestine supplied by RUP and by microbial protein from rumen-fermented OM (INRA, 1989).

CE, 3/09/99-Norme NF EN ISO 13903). Analyses of Met and Cys were performed after the initial oxidation of samples with performic acid. Phenylalanine was analyzed without oxidation, whereas Trp was analyzed after hydrolysis in $4 \mathrm{MBa}(\mathrm{OH})_{2}$ at $110^{\circ} \mathrm{C}$ for $16 \mathrm{~h}(\mathrm{Af}-$ nor XPV 18-114). The concentrations of digestible AA in the small intestine (AADI), expressed in percentage of PDIE, were calculated using the measurements proposed by Rulquin et al. $(1998,2001)$.

Milk production was recorded at each milking, and samples were assayed by infrared analysis using a MilkoScan 605 instrument (Foss Electric, Hillerød, Denmark) to determine protein, fat, and lactose contents at each milking. On the last day of each period, milk was sampled from the morning and evening milk- ing to determine total N, NPN, and non-CN N according to the Kjeldahl method. On the last day of each period, 2 blood samples were collected from the jugular vein of each cow in heparinized syringes (S-Monovette, $7.5 \mathrm{~mL}$; Sarstedt, Nümbrecht, Germany) at 0800 and $0815 \mathrm{~h}$ (i.e., 30 and 45 min after milking, and 30 and 15 min before feed distribution) and were immediately centrifuged $\left(2,000 \times g\right.$ for 15 min at $\left.4^{\circ} \mathrm{C}\right)$. Plasma was aliquoted and stored at $-80^{\circ} \mathrm{C}$ for $\mathrm{AA}$ analyses and at $-20^{\circ} \mathrm{C}$ for the analysis of urea, NEFA, BHBA, triacylglycerol (TG), and glucose. Plasma AA and 3-methylHis concentrations were determined by using an ultraperformance liquid chromatography-mass spectrometry system (Waters Acquity UltraPerformance LC system; Waters, Guyancourt, France).

Plasma samples for NEFA, TG, BHBA, urea, and glucose were assayed by colorimetric enzymatic reaction with a multiparameter analyzer (Kone Instruments Corporation, Espoo, Finland). The enzymatic kits used for NEFA, TG, BHBA, and urea were a NEFA-C test kit (Wako Chemicals GmbH, Neuss, Germany), TG PAP 1000 kit (bioMérieux, Craponne, France), 3-hydroxybutyrate dehydrogenase kit (Rabut-Randox, Mauguio, France), and urease and glutamate dehydrogenase kit (Urée UV Cinétique, Kone Diagnostics, Evry, France) respectively. Glucose was analyzed through 2 successive enzymatic reactions catalyzed by a hexokinase and glucose-6-phosphate dehydrogenase (Horiba ABX; ABX Pentra, Montpellier, France).

\section{Calculations and Statistics}

The $\mathrm{N}$ efficiency of conversion was calculated by using following equation:

$$
\mathrm{N} \text { efficiency }=\frac{\mathrm{N} \text { in milk }}{\mathrm{N} \text { in } \mathrm{CP}+\mathrm{N} \text { infused }} \text {, }
$$

Data were analyzed using the MIXED procedure of SAS (SAS Institute, 2004) according to the following statistical model:

$$
\mathrm{Y}_{\mathrm{ijk}}=\mu+\mathrm{Cow}_{\mathrm{i}}+\operatorname{Period}_{\mathrm{j}}+\mathrm{AA}_{\mathrm{k}}+\varepsilon_{\mathrm{ijk}},
$$

where $Y_{\mathrm{ijk}}$ is the response variable, $\mu$ is the grand mean, and $\varepsilon$ is the random error; $\mathrm{Cow}_{\mathrm{i}}$ was taken as the random effect. Contrast statements were included to compare (1) CTRL versus - Arg, (2) CTRL versus - Ile, and (3) CTRL versus - Val. The Dunnett adjustment was used to correct for nonorthogonality (SAS Institute, 2004). The maximum number of available observations (i.e., $\mathrm{n}=16)$ was used. The significance level was set to $P$ $\leq 0.05$, and the tendency was set to $0.05>P \leq 0.10$. 
Table 4. Dry matter intake, protein, and energy supplies

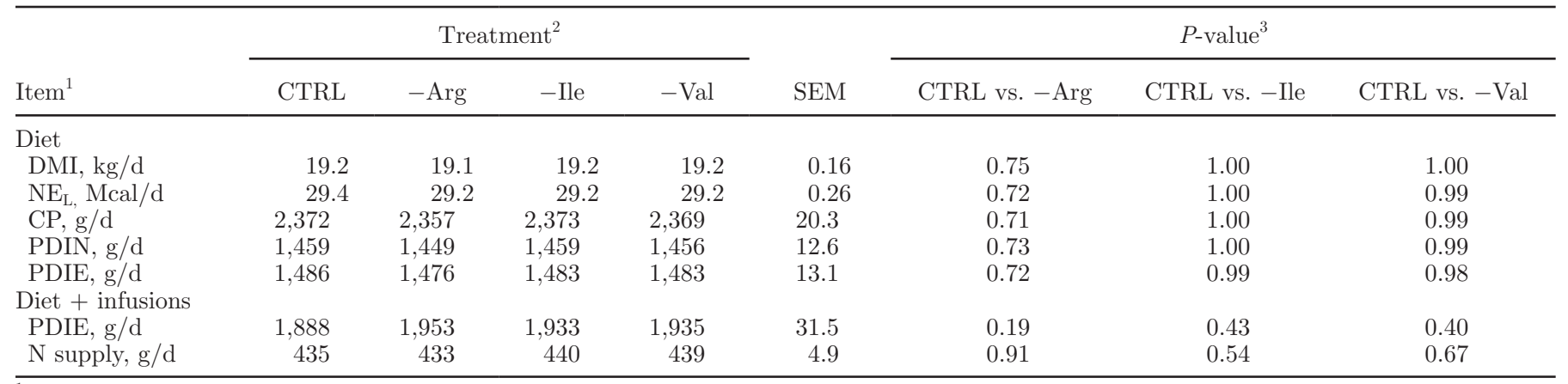

${ }^{1} \mathrm{PDIN}=$ protein digested in the small intestine supplied by RUP and by microbial protein from rumen-degraded dietary N (INRA, 1989); PDIE $=$ protein digested in the small intestine supplied by RUP and by microbial protein from rumen-fermented OM (INRA, 1989); $\mathrm{N}$ supply = $\mathrm{N}$ in $\mathrm{CP}+\mathrm{N}$ infused.

${ }^{2} \mathrm{CTRL}=\mathrm{Arg}$, Ile, and Val included in the AA mixture; $-\mathrm{Arg}=$ Arg removed from the AA mixture; - Ile = Ile removed from the AA mixture; - Val $=$ Val removed from the AA mixture.

${ }^{3}$ Probability corresponds to the following comparisons: (1) CTRL vs. -Arg, (2) CTRL vs. -Ile, and (3) CTRL vs. -Val.

\section{RESULTS}

\section{DMI, Protein and Energy Supplies, and Estimated Intestinal AA Flow}

No refusal of the offered diet was observed in any of the treatments, and because the DM offered was fixed, the DMI remained unaffected by the treatments. Consequently, neither the protein (CP, PDIE, and PDIN) nor the energy $\left(\mathrm{NE}_{\mathrm{L}}\right)$ supplies were modified (Table 4). Treatments (diet and infusion) were isonitrogenous and the supply of $66.0 \pm 1.2 \mathrm{~g}$ of PDIE/Mcal of $\mathrm{NE}_{\mathrm{L}}$ was similar to the target.

The estimated intestinal supplies of AA from the diet and infusions are reported in Table 5. The estimated values for the 3 test AA (Arg, Ile, and Val) were close to the target. The supply of the Arg treatment in the intestine (ArgDI) was 3.5\% of PDIE in - Arg, compared with $5.2 \%$ of PDIE in the CTRL treatment; Ile was $4.1 \%$ of PDIE in -Ile, compared with $5.2 \%$ of PDIE in the CTRL treatment; and Val was $4.5 \%$ of PDIE in -Val, compared with $5.9 \%$ of PDIE in the CTRL treatment. Because the supply of Glu and Ser was slightly higher in the -Arg treatment, the predicted flow of certain infused EAA (such as Lys and Phe) was slightly lower than in the other treatments; however, it was within the range of variation (SD: $0.3 \%$ of PDIE) proposed by Rulquin et al. (1993). The estimated supply of Leu in the diet (9.0\% of PDIE) was lower than the targeted one (9.4\% of PDIE); hence, all treatments (diet and infusions) were deficient in Leu (8.4\% of PDIE, compared with $8.9 \%$ of PDIE as targeted). By contrast, the diet provided a higher concentration of Phe ( $5.1 \%$ of PDIE) and Tyr (5.2\% of PDIE) as compared with the target (4.6\% Phe and $4.0 \%$ Tyr; \% of PDIE). Consequently, the supply of Phe + Tyr through the diet and infusions was higher $(9.9 \%$ of PDIE) than the target $(9.2 \%$ of PDIE).

\section{Milk Production}

Milk yield was not modified by any of the treatments (Table 6). The deletion of Arg (CTRL vs. - Arg) and Ile (CTRL vs. - Ile) from the infusion mixture had no effect on milk protein yield or content $(P>0.10)$. The deletion of Val from the infusion mixture decreased milk protein and CP contents by 4.9 and $4.3 \%$, respectively (contrast CTRL vs. - Val: $P=0.05$ ). The deletion of Val tended to decrease milk protein yield and the efficiency of $\mathrm{N}$ use by 3.5 and $3.7 \%$, respectively $(P=$ $0.10)$. Neither fat yield and content nor lactose yield and content was modified by any of the treatments; however, the ratio of protein to fat content in milk tended to decrease in -Ile compared with the CTRL treatment by $3.8 \%$ (CTRL vs. Ile: $P=0.07$ ).

\section{Plasma AA and Metabolite Concentrations}

The plasma concentration of Arg was not affected by its removal from the infusion mixture (Table 7; CTRL vs. - Arg: $P>0.10)$. The removal of Ile tended to decrease its plasma concentration by $34 \%$ (CTRL vs. Ile: $P=0.10)$. The removal of Val decreased its plasma concentration by $52 \%$ (CTRL vs. - Val: $P<0.01$ ). Furthermore, removing Val from the infusion mixture (CTRL vs. - Val) tended to decrease the plasma concentrations of Met and His by 26 and 25\%, respectively $(P=0.10)$. Adding Ser and Glu as replacements for the 3 test EAA (Arg, Ile, and Val) in the infusion mixtures had no effect on their plasma concentration $(P>0.10)$. By removing Val from the infusion mixture, the plasma 
Table 5. Predicted intestinal flows of digestible AA from diet and diet plus infusions, and predicted concentrations of AA in PDIE ${ }^{1}$

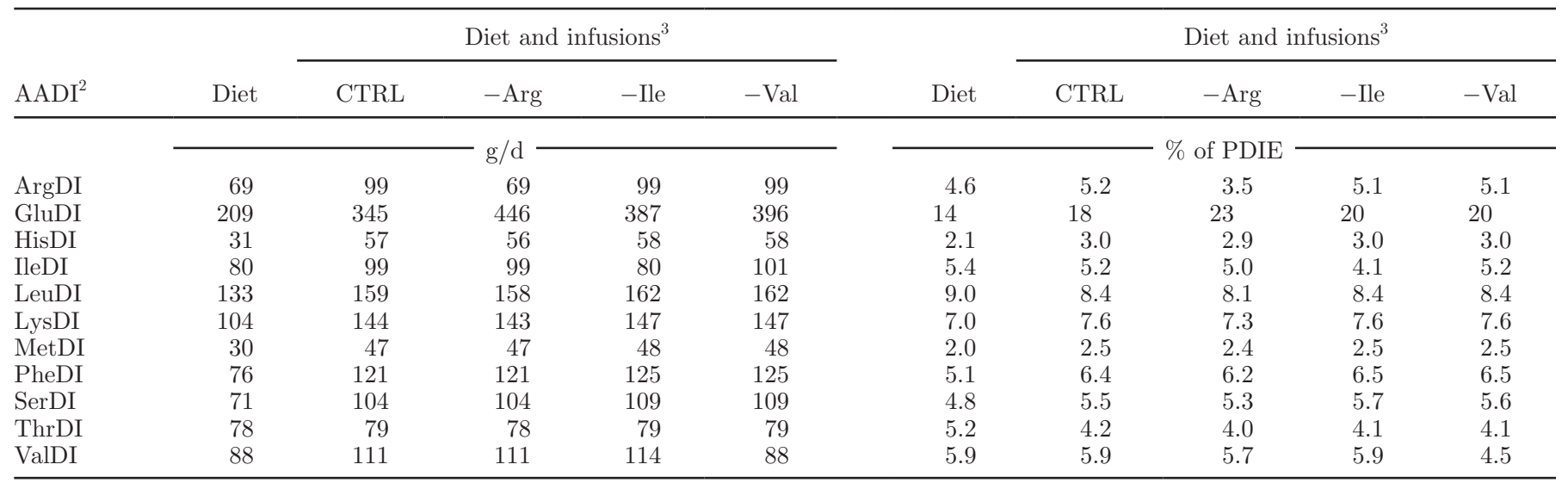

${ }^{1}$ PDIE $=$ protein digested in the small intestine supplied by RUP and by microbial protein from rumen-fermented OM (INRA, 1989).

${ }^{2} \mathrm{AADI}=\mathrm{AA}$ digestible in the small intestine $[1 \mathrm{~g}$ of AADI is equal to $1 \mathrm{~g}$ of PDIE; Rulquin et al. (1998, 2001) and INRA (2007)]. The AADI system does not account for Trp and Cys.

${ }^{3} \mathrm{CTRL}=\mathrm{Arg}$, Ile, and Val included in the AA mixture; - Arg = Arg removed from the AA mixture; -Ile = Ile removed from the AA mixture; $-\mathrm{Val}=$ Val removed from the AA mixture.

concentration of the branched-chain AA (BCAA) decreased by $28 \%(P=0.04)$, whereas the sums of EAA and of NEAA tended to decrease by $23 \%(P=$ $0.10)$ and $17 \%(P=0.08)$, respectively. The plasma concentration of 3-methyl-His was not modified by the treatments. The removal of Arg, Ile, or Val from the infusion mixtures had no effect on the concentration of measured plasma metabolites (Table 8).

\section{DISCUSSION}

Our objective in this experiment was to create large differences in the intestinal supply of Arg, Ile, and Val and to study the effect of their reduced supplies on lactation performance. The differences between the CTRL and negative treatments were created by feeding a protein-deficient diet and compensating for the desired

Table 6. Milk yield and composition

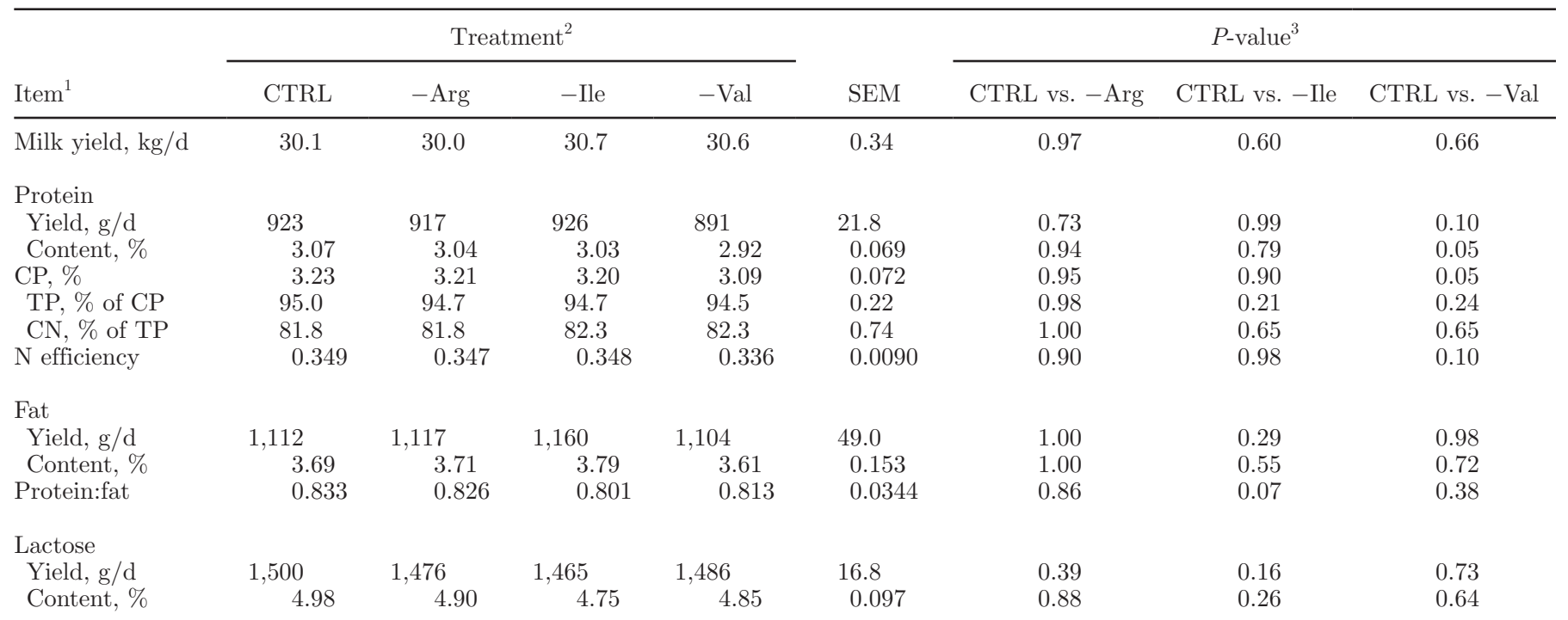

${ }^{1} \mathrm{CP}=$ total $\mathrm{N} \times 6.39$ in the INRA (2007) system; $\mathrm{TP}=$ true protein; $\mathrm{N}$ efficiency $=\mathrm{N}$ in milk $/ \mathrm{N}$ in $\mathrm{CP}+\mathrm{N}$ infused; protein:fat $=$ protein content/fat content.

${ }^{2} \mathrm{CTRL}=\mathrm{Arg}$, Ile, and Val included in the AA mixture; $-\mathrm{Arg}=$ Arg removed from the AA mixture; - Ile = Ile removed from the AA mixture; $-\mathrm{Val}=$ Val removed from the AA mixture.

${ }^{3}$ Probability corresponds to the following comparisons: (1) CTRL vs. -Arg, (2) CTRL vs. -Ile, and (3) CTRL vs. -Val. 
Table 7. Plasma AA concentrations

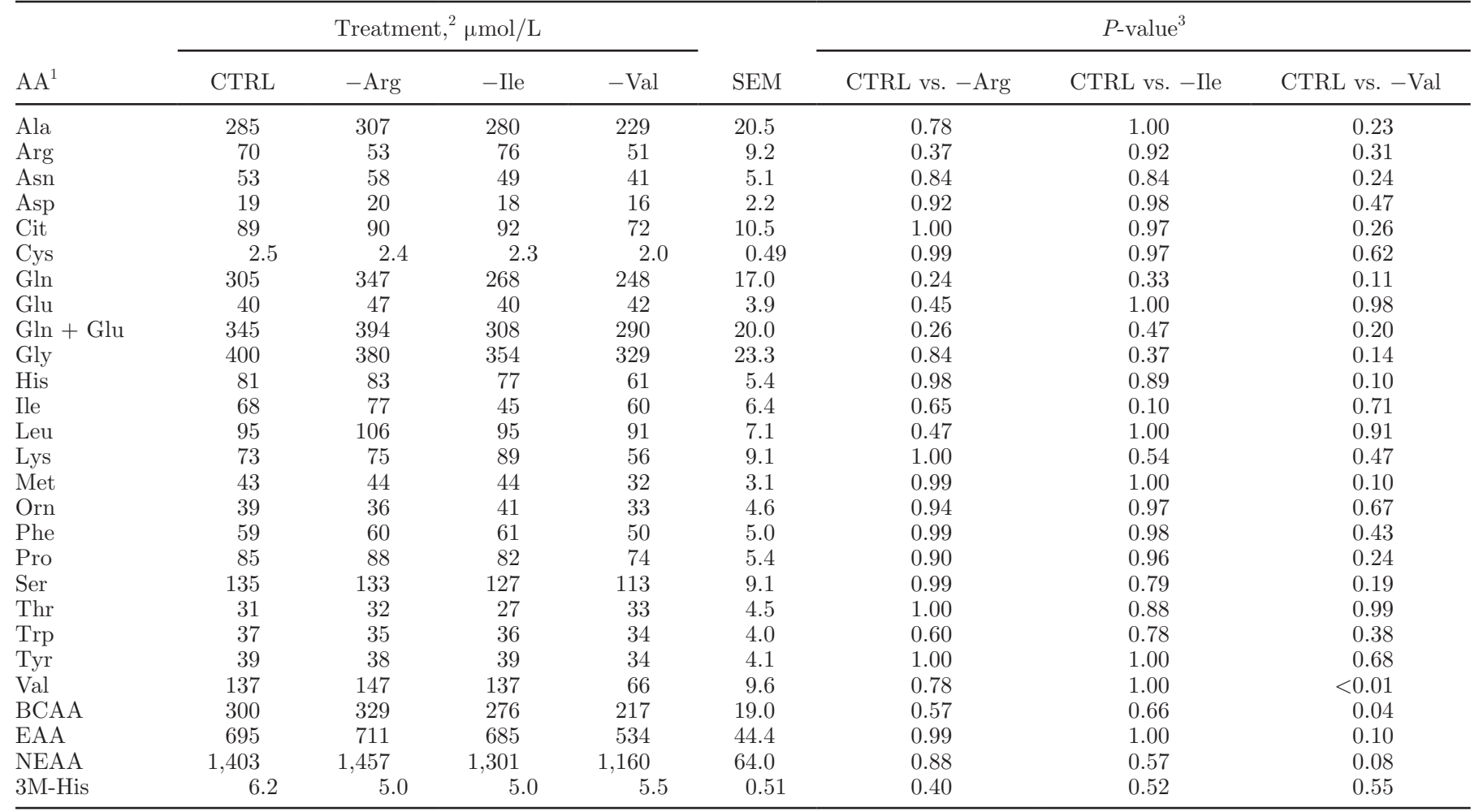

${ }^{1}$ BCAA (branched-chain AA) = sum of Ile, Val, and Leu; EAA (essential AA) = sum of Arg, Ile, Val, Leu, Lys, Met, His, Phe, Trp, and Thr; NEAA (nonessential AA) = sum of Glu, Ser, Ala, Asn, Asp, Cys, Gln, Gly, Orn, Pro, and Tyr; 3M-His = 3-methyl-His.

${ }^{2} \mathrm{CTRL}=\mathrm{Arg}$, Ile, and Val included in the AA mixture; -Arg = Arg removed from the AA mixture; -Ile = Ile removed from the AA mixture; - Val $=$ Val removed from the AA mixture.

${ }^{3}$ Probability corresponds to the following comparisons: (1) CTRL vs. $-\mathrm{Arg}$, (2) CTRL vs. -Ile, and (3) CTRL vs. -Val.

availability of AA via intestinal infusion (Table 5). The estimated intestinal supplies of Arg, Ile, and Val were (in \% of PDIE) 5.2, 5.2, and 5.9\%, respectively, whereas upon removal from the infusion mixtures, their supplies decreased by 33,21 , and $24 \%$ in the -Arg, - Ile, and Val treatments, respectively. Compared with the lowest recommended supply levels in the literature for these AA (Table 9; Fraser et al., 1991), the supply of Arg was $13 \%$ higher, Ile was $10 \%$ lower, and Val was $18 \%$ lower in the $-\mathrm{Arg},-\mathrm{Ile}$, and - Val treatments, respectively. On the other hand, the supplies of Arg, Ile, and Val in the CTRL treatment were close to the highest levels recommended in the literature (Doepel et al., 2004).

\section{A Deficiency of Val Decreased Milk Protein Synthesis}

We observed a decrease in milk protein content and a tendency toward decreasing milk protein yield when

Table 8. Plasma concentrations of urea and energy metabolites

\begin{tabular}{|c|c|c|c|c|c|c|c|c|}
\hline \multirow[b]{2}{*}{ Item } & \multicolumn{4}{|c|}{ Treatment $^{1}$} & \multirow[b]{2}{*}{ SEM } & \multicolumn{3}{|c|}{$P$-value ${ }^{2}$} \\
\hline & CTRL & $-\operatorname{Arg}$ & -Ile & $-\mathrm{Val}$ & & CTRL vs. - Arg & CTRL vs. - Ile & CTRL vs. - Val \\
\hline Urea, $\mathrm{m} M$ & 2.62 & 2.95 & 3.15 & 3.26 & 0.390 & 0.62 & 0.31 & 0.20 \\
\hline Glucose, $\mathrm{m} M$ & 3.90 & 3.89 & 3.81 & 4.08 & 0.094 & 1.00 & 0.73 & 0.23 \\
\hline NEFA, $\mu M$ & 107 & 106 & 143 & 154 & 23.6 & 1.00 & 0.41 & 0.23 \\
\hline $\mathrm{BHBA}, \mathrm{m} M$ & 0.59 & 0.68 & 0.66 & 0.72 & 0.081 & 0.59 & 0.72 & 0.36 \\
\hline $\mathrm{TG}^{3}{ }^{3} \mu M$ & 78.6 & 74.7 & 83.1 & 79.9 & 9.32 & 0.81 & 0.75 & 0.99 \\
\hline
\end{tabular}

${ }^{1} \mathrm{CTRL}=$ Arg, Ile, and Val included in the AA mixture; - Arg = Arg removed from the AA mixture; -Ile = Ile removed from the AA mixture; $-\mathrm{Val}=$ Val removed from the AA mixture.

${ }^{2}$ Probability corresponds to the following comparisons: (1) CTRL vs. -Arg, (2) CTRL vs. -Ile, and (3) CTRL vs. -Val.

${ }^{3} \mathrm{TG}=$ triacylglycerol. 
Table 9. Comparison of the literature recommended ideal concentrations of the branched-chain AA and Arg for dairy cows

\begin{tabular}{|c|c|c|c|c|c|}
\hline AA & \multicolumn{4}{|c|}{ Recommendations for dairy cows } & $\begin{array}{c}\text { Profile in milk } \\
\begin{array}{c}\text { Swaisgood } \\
(1995)\end{array}\end{array}$ \\
\hline Leu & 8.0 & 9.0 & 9.4 & 8.9 & 9.1 \\
\hline Ile & 4.5 & 5.2 & 5.3 & 4.5 & 5.5 \\
\hline Val & 5.3 & 5.9 & 6.1 & 5.3 & 6.1 \\
\hline
\end{tabular}

${ }^{1}$ Recommendations for Arg, Ile, and Val from Fraser et al. (1991).

${ }^{2} \mathrm{PDIE}=$ protein digested in the small intestine supplied by RUP and by microbial protein from rumen-fermented OM (INRA, 1989).

${ }^{3} \mathrm{TP}=$ true protein.

the supply of Val was decreased (from 5.9 to $4.5 \%$ of PDIE). The decrease in milk protein synthesis was accompanied not only by a decrease in plasma concentration of Val, but also by a trend toward decreases in Met, His, the sum of EAA, and the sum of NEAA, indicating a change in utilization of these EAA with a Val deficiency. The specific effects on milk protein synthesis observed in this experiment with Val are not in accordance with the literature (Schwab et al., 1976; Korhonen et al., 2002). Korhonen et al. (2002) reported an absence of response with the removal of Val from a mixture of His + BCAA $[5.8 \%$ vs. $6.9 \%$ of PDIE, respectively; recalculated by using INRA (2007)] in a grass silage-based diet. Clearly, in the study by Korhonen et al. (2002), Val was not deficient when compared with the recommendations in the literature (Table 9). The experiment by Schwab et al. (1976), in which corn silage was fed ad libitum, increasing the supply of Val from 4.7 to $5.9 \%$ of PDIE [recalculated by using INRA (2007)], showed both an increase $(+0.8 \mathrm{~g} / \mathrm{kg}$; similar to the $1.1 \mathrm{~g} / \mathrm{kg}$ in this experiment) and no response in milk CP content. In the present experiment, 2 hypotheses can partially explain the decrease in milk protein synthesis caused by the Val-deficient treatment.

Hypothesis 1: The Deficiency of Val in Conjugation with Leu Decreased Milk Protein Synthesis. An unexpected result of this experiment was that all treatments were deficient in Leu (Table 5) because its intestinal supply was less (8.4\% of PDIE) than expected ( $8.9 \%$ of PDIE). The estimated intestinal supply of Leu (8.4\% of PDIE; Table 5) was closer to the lowest recommended levels proposed by Fraser et al. (1991), which is well below the recommendations of other reports (Rohr and Lebzien, 1991; Doepel et al., 2004; Rulquin and Pisulewski, 2006). To further analyze this, 6 experiments from the literature specifically designed to examine the effect of postruminal supplementation of Leu on milk protein synthesis were regrouped. The basal diets used in these experiments were principally composed of either corn silage (Kröber et al., 2001; Rulquin and Pisulewski, 2006; Kř́žová et al., 2008) or grass silage (Huhtanen et al., 2002; Korhonen et al., 2002; Richter et al., 2010). When the results (Figure 1) were analyzed, only the lowest threshold level of Leu supply for milk protein content could be proposed (i.e., 8.9 to $9.0 \%$ of PDIE), which is closer to the recommendations of Rulquin and Pisulewski (2006). Hence, the possibility that milk protein synthesis was affected

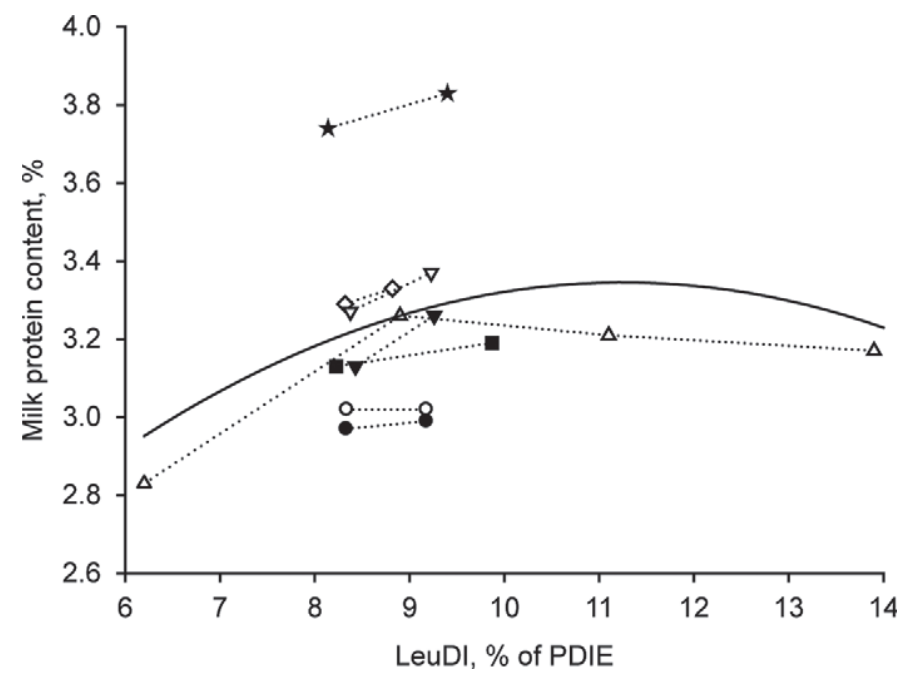

Figure 1. Milk protein content in response to Leu supply in the literature. Data points from the same experiment were connected with dotted lines. The solid line is the regression line made by using the quadratic model. Symbols correspond to data from the following studies: (solid and open circles) Huhtanen et al. (2002); (solid squares) Korhonen et al. (2002); (upward-pointing open triangles) Rulquin and Pisulewski (2006); (solid stars) Richter et al. (2010); (downward-pointing solid and open triangles) Kröber et al. (2001); (open diamonds) Kř́žová et al. (2008). The resultant equation for the quadratic model was $\mathrm{Y}_{\mathrm{ij}}=1.4( \pm 0.38)+0.34( \pm 0.074) \times \mathrm{X}_{\mathrm{i}}+0.015( \pm 0.0037) \times \mathrm{X}_{\mathrm{i}}{ }^{2}$ (adjusted $\mathrm{R}^{2}=0.95$, and residual $\left.\mathrm{SD}=0.030\right)$. LeuDI $=$ Leu digested in the small intestine; PDIE = protein digested in the small intestine supplied by RUP and by microbial protein from rumen-fermented OM (INRA, 1989). 
because of a cumulative deficiency of Leu and Val could not be excluded in this experiment.

Hypothesis 2: Interactions and Antagonisms Among the BCAA Decreased Milk Protein Synthesis. The negative effect on milk protein yield observed in the -Val treatment could possibly be a result of an imbalance between Val, Leu, and Ile supplies because this treatment can be translated as a low-Val, low-Leu, and high-Ile supply. The presence of antagonisms and interactions among BCAA has been known for many years. In laying hens, a supply of a similar combination of these 3 BCAA (+Ile, -Leu, and - Val) has been shown to reduce their overall production performance, characterized by decreased feed intake, egg production, egg weight, and daily egg mass (Peganova and Eder, 2003). In the current experiment, we observed no effect on DMI because the quantity of DM offered was fixed and the duration of treatments was not long enough to observe changes in intake. A higher Leu supply (in studies based on rats, chicks, and bacteria) is related to the depletion of Ile and Val pools, which causes an increase in the requirements of these 2 AA (see the review by Harper et al., 1984). Similarly, a study on lactating porcine mammary tissue has shown that Leu inhibits Val uptake (Jackson et al., 2000). In dairy cows, the BCAA are categorized among the group 2 AA (Lys + BCAA) because they are principally catabolized in mammary glands, compared with group 1 AA (Met, His, Phe, Trp, and Tyr), which are catabolized in the liver (Mepham, 1982). Consequently, an excess or deficiency of one BCAA may interfere with the mammary use of the other 2 BCAA. The presence of this antagonism may explain why no studies designed to examine the effect of supplying BCAA on milk protein in dairy cows (Mackle et al., 1999; Weekes et al., 2006; Appuhamy et al., 2011) have reported an effect, because increasing or decreasing the supply of BCAA altogether did not modify the ratio among them.

\section{Responses to the Deficiency of Ile}

We observed no response to decreasing the supply of Ile (4.1 vs. $5.2 \%$ of PDIE) on milk yield, milk protein yield, or milk protein content, which is in agreement with the results of Korhonen et al. (2002), in which Ile concentration varied from 5.2 to $6.1 \%$ of PDIE [recalculated using INRA (2007)]. The small increase in milk protein content observed by Schwab et al. (1976), achieved by supplying Ile $[4.9 \%$ vs. $6.1 \%$ of PDIE, recalculated using INRA (2007)] along with Met, Lys, and Val, was not observed in this experiment. Similarly, the decrease in lactose yield observed by Robinson et al. (1999), achieved by decreasing the Ile supply $(5.2 \%$ vs. $6.4 \%$ of PDIE, recalculated using INRA (2007)], was also not observed in the current experiment. However, we did observe a trend toward decreasing milk protein-to-fat content ratios, which is often described as an indicator of AA imbalance (Cant et al., 2003; Weekes et al., 2006). This change in the protein-to-fat content ratio was more closely related to changes in fat than to changes in protein content (Table 6). Previous studies to test the Ile deficiency in dairy cows have reported that Ile has no effect on milk fat yield or content (Schwab et al., 1976; Robinson et al., 1999; Korhonen et al., 2002). In terms of BCAA, Hopkins et al. (1994) reported that an increase in the supply of BCAA + Arg could decrease milk fat depression when cows were fed low-fiber diets. However, other studies have reported that supplying BCAA had no effect on milk fat yield and content (Mackle et al., 1999; Weekes et al., 2006; Appuhamy et al., 2011). Nevertheless, deficiencies of Lys and His have been shown to increase milk fat yield (Weekes et al., 2006). Again, both assumptions previously used to explain the negative effect on milk protein in -Val treatments apply equally here: The decrease in milk protein-to-fat content ratio was a result either of the deficiency of both Ile and Leu or of antagonism among the $3 \mathrm{BCAA}$. It can be concluded that at least the AA profile in the -Ile treatment was not an ideal profile because an incomplete correction of the EAA profile leads to a decreased milk protein-to-fat ratio (Cant et al., 2003).

\section{No Response by Decreasing the Supply of Arg}

We observed no response on milk yield and its composition by decreasing the supply of Arg, which is in accordance with earlier reports (Schwab et al., 1976; Vicini et al., 1988; Doepel and Lapierre, 2011). It can be concluded that under the current experimental situation, a supply of $3.5 \%$ of PDIE, which is close to the $3.1 \%$ of PDIE proposed by Fraser et al. (1991), can serve as an optimal level, as opposed to the higher level (4.8\% of PDIE) proposed by Doepel et al. (2004).

\section{CONCLUSIONS}

The objective of this experiment was to advance our knowledge to construct an ideal AA profile for dairy cows. In the case of Arg, an intestinal supply of 3.5\% of PDIE seems sufficient because, at higher levels, we observed no response on milk protein synthesis. The experiment confirmed that a lower level of Val $(4.5 \%$ of PDIE) supply had a negative effect on milk protein yield. The experiment also indicated that a lower level of Ile ( $4.1 \%$ of PDIE) did not correspond to an ideal profile because of the trend toward a decreased milk protein-to-fat ratio. Dose-response experiments are re- 
quired to evaluate the optimal supply levels of these 2 AA. The specific effects of these $2 \mathrm{AA}$ (Ile and Val) in this experiment could also be related to the low supply of Leu ( $8.4 \%$ of PDIE), which affected both lactation performance and the presence of possible antagonism among these 3 BCAA. We propose that future systems for AA feeding in dairy cows consider the antagonism among BCAA when establishing their requirements.

\section{ACKNOWLEDGMENTS}

The authors are grateful to C. Mustière for AA analyses; N. Huchet, M. Texier, S. Marion, and N. Mezière for their help in laboratory analyses; R. Delagarde for the surgical preparation of animals; and P. Lamberton, D. Chevrel, A. Cozien, M. Lemarchand, J. L. Harel, and J. I. Thibaud for technical support and animal care during the experiments. The authors wish to acknowledge Adisseo (Commentry, France) for financially supporting the research and supplying DL-Met in this experiment, and Estelle Devillard (Centre of Expertise Research and Nutrition, Adisseo) for helpful discussions. The first author also wishes to acknowledge the Higher Education Commission of Pakistan (Islamabad) for a scholarship to pursue his doctoral degree. The authors also acknowledge Ajinomoto for supplying AA at low prices for this research. This study was granted by the Commission of the European Communities (project FP7-KBBE-2007-1 "Rednex").

\section{REFERENCES}

Appuhamy, J. A. D. R., J. R. Knapp, O. Becvar, J. Escobar, and M. D. Hanigan. 2011. Effects of jugular-infused lysine, methionine, and branched-chain amino acids on milk protein synthesis in highproducing dairy cows. J. Dairy Sci. 94:1952-1960.

Cant, J. R., R. Berthiaume, H. Lapierre, P. H. Luimes, B. W. McBride, and D. Pacheco. 2003. Responses of the bovine mammary glands to absorptive supply of single amino acids. Can. J. Anim. Sci. 83:341-355.

Doepel, L., and H. Lapierre. 2011. Deletion of arginine from an abomasal infusion of amino acids does not decrease milk protein yield in Holstein cows. J. Dairy Sci. 94:864-873.

Doepel, L., D. Pacheco, J. J. Kennelly, M. D. Hanigan, I. F. Lopez, and H. Lapierre. 2004. Milk protein synthesis as a function of amino acid supply. J. Dairy Sci. 87:1279-1297.

Fraser, D. L., E. R. Orskov, F. G. Whitelaw, and M. F. Franklin. 1991. Limiting amino-acids in dairy-cows given casein as the sole source of protein. Livest. Prod. Sci. 28:235-252.

Harper, A. E., R. H. Miller, and K. P. Block. 1984. Branched-chain amino acid metabolism. Annu. Rev. Nutr. 4:409-454.

Hopkins, B. A., A. H. Rakes, T. E. Daniel, C. A. Zimmerman, and W. J. Croom Jr. 1994. Effects of intraperitoneal L-leucine, L-isoleucine, L-valine, and L-arginine on milk fat depression in early lactation cows. J. Dairy Sci. 77:1084-1092.

Huhtanen, P., A. Vanhatalo, and T. Varvikko. 2002. Effects of abomasal infusions of histidine, glucose, and leucine on milk production and plasma metabolites of dairy cows fed grass silage diets. J. Dairy Sci. 85:204-216.

INRA. 1989. Ruminant Nutrition: Recommended Allowances and Feed Tables. INRA Editions, Paris, France.
INRA. 2007. Nutrition of Cattle, Sheep and Goats: Animal NeedsValues of Feeds. Quae Editions, Paris, France.

Jackson, S. C., J. M. Bryson, H. Wang, and W. L. Hurley. 2000. Cellular uptake of valine by lactating porcine mammary tissue. J. Anim. Sci. 78:2927-2932.

Korhonen, M., A. Vanhatalo, and P. Huhtanen. 2002. Evaluation of isoleucine, leucine, and valine as a second-limiting amino acid for milk production in dairy cows fed grass silage diet. J. Dairy Sci. 85:1533-1545.

Kř́žová, L., J. Trinacty, M. Richter, S. Hadrova, and J. Pozdisek. 2008. Effect of ruminally-protected leucine supplement on milk yield and plasma amino acids in dairy cows. Agric. Food Sci. $17: 351-359$.

Kröber, T. F., F. Sutter, M. Senn, W. Langhans, and M. Kreuzer. 2001. Effects of supplying leucine and methionine to early-lactating cows fed silage-concentrate based diets with a calculated deficiency in leucine and methionine. Anim. Res. 50:5-20.

Mackle, T. R.. D. A. Dwyer, and D. E. Bauman. 1999. Effects of branched-chain amino acids and sodium caseinate on milk protein concentration and yield from dairy cows. J. Dairy Sci. 82:161-171.

Mepham, T. B. 1982. Amino acid utilization by lactating mammary gland. J. Dairy Sci. 65:287-298.

NRC. 2001. Nutrient Requirements of Dairy Cattle. 7th rev. ed. Nat. Acad. Sci., Washington, DC.

Peganova, S., and K. Eder. 2003. Interactions of various supplies of isoleucine, valine, leucine and tryptophan on the performance of laying hens. Poult. Sci. 82:100-105.

Richter, M., J. Svobodova, L. Krizova, J. Trinacty, and P. Homolka. 2010. Effect of duodenal infusions of leucine on milk yield and plasma amino acids in dairy cows. Czech J. Anim. Sci. 55:351358.

Robinson, P. H., W. Chalupa, C. J. Sniffen, W. E. Julien, H. Sato, T. Fujieda, K. Watanabe, and H. Suzuki. 1999. Influence of postruminal supplementation of methionine and lysine, isoleucine, or all three amino acids on intake and chewing behavior, ruminal fermentation, and milk and milk component production. J. Anim. Sci. $77: 2781-2792$.

Rohr, K., and P. Lebzien. 1991. Present knowledge of amino acid requirements for maintenance and production. Pages 127-137 in Proc. 6th Int. Symp. Protein Metab. Nutr. Eur. Assoc. Anim. Prod. Publ. No. 59. Wageningen Academic Publishers, Wageningen, the Netherlands.

Rulquin, H., J. Guinard, and R. Verite. 1998. Variation of amino acid content in the small intestine digesta of cattle: Development of a prediction model. Livest. Prod. Sci. 53:1-13.

Rulquin, H., and P. M. Pisulewski. 2006. Effects of graded levels of duodenal infusions of leucine on mammary uptake and output in lactating dairy cows. J. Dairy Res. 73:328-339.

Rulquin, H., P. M. Pisulewski, R. Verite, and J. Guinard. 1993. Milkproduction and composition as a function of postruminal lysine and methionine supply-A nutrient-response approach. Livest. Prod. Sci. 37:69-90.

Rulquin, H., G. Raggio, H. Lapierre, and S. Lemosquet. 2007. Relationship between intestinal supply of essential amino acids and their mammary metabolism in the lactating dairy cow. Pages 587-588 in Energy and Protein Metabolism and Nutrition. Eur. Assoc. Anim. Prod. Publ. No. 124. Wageningen Academic Publishers, Wageningen, the Netherlands.

Rulquin, H., R. Verite, J. Guinard-Flament, and P. M. Pisulewski. 2001. Amino acids truly digestible in the small intestine. Factors of variation in ruminants and consequences on milk protein secretion. Prod. Anim. 14:201-210.

SAS Institute. 2004. SAS System for Mixed Models. SAS Inst. Inc., Cary, NC.

Schwab, C. G. 1996. Amino acid nutrition of the dairy cow: Current status. Pages 184-198 in Proc. Cornell Nutr. Conf., Ithaca, NY. College of Agriculture and Life Sciences, Cornell University, Ithaca, NY.

Schwab, C. G., L. D. Satter, and A. B. Clay. 1976. Response of lactating dairy cows to abomasal infusion of amino acids. J. Dairy Sci. $59: 1254-1270$. 
Swaisgood, H. E. 1995. Protein and amino acid composition of bovine milk. Pages 464-471 in Handbook of Milk Composition. R. G. Jensen, ed. Academic Press, San Diego, CA.

Vérité, R., and L. Delaby. 2000. Relation between nutrition, performances and nitrogen excretion in dairy cows. Ann. Zootech. 49:217-230.

Vicini, J. L., J. H. Clark, W. L. Hurley, and J. M. Bahr. 1988. Effects of abomasal or intravenous administration of arginine on milk production, milk composition, and concentrations of somatotropin and insulin in plasma of dairy cows. J. Dairy Sci. 71:658-665.

Weekes, T. L., P. H. Luimes, and J. P. Cant. 2006. Responses to amino acid imbalances and deficiencies in lactating dairy cows. J. Dairy Sci. 89:2177-2187.

Wohlt, J. E., J. H. Clark, R. G. Derrig, and C. L. Davis. 1977. Valine, leucine, and isoleucine metabolism by lactating bovine mammary tissue. J. Dairy Sci. 60:1875-1882. 